\title{
Giant Globular (Biconvex) Chronic Subdural Hematoma
}

\section{Hematoma subdural crônico globular (biconvexo) gigante}

\author{
Paulo Roberto Louzada ${ }^{1,2}$ Juliana Jarruj Beliki² \\ ${ }^{1}$ Instituto de Ciências Biomédicas, Universidade Federal do Rio de \\ Janeiro, Rio de Janeiro, Brazil \\ 2 Neurosurgery Service, Hospital Municipal Souza Aguiar, Rio de \\ Janeiro, Brazil
}

Arq Bras Neurocir 2016;35:319-322.

\begin{abstract}
Address for correspondence Paulo Roberto Louzada, MD, PhD, Instituto de Ciências Biomédicas, Universidade Federal do Rio de Janeiro, Av. Carlos Chagas Filho, 373, Bloco K, $2^{\circ}$ andar, sala 35, Cidade Universitária, CEP 21.941-902, Rio de Janeiro, RJ, Brazil (e-mail: profpaulolouzada@yahoo.com.br).
\end{abstract}

\section{Abstract \\ Keywords \\ - hydrocephalus \\ - ventriculoperitoneal shunt \\ - traumatic brain injury \\ - subdural hematoma \\ - globular hematoma}

\section{Resumo}

Palavras-chave

- hidrocefalia

- shunt ventriculoperitoneal

- traumatismo encefálico

- hematoma subdural

- hematoma globular
Introduction Hydrocephalus is a frequent neurological condition in childhood. The most common approach to this disease is still ventricular shunting. However, shunting problems, including catheter infection or shunting malfunctioning, contribute to several complications, such as extra-axial hematomas, which are a possibly lifethreatening.

Case report We report the case of a 6-month-old female infant victim of brain trauma. She was previously shunted because of an obstructive hydrocephalus consequent of an aqueductal stenosis diagnosed early after birth. After brain injury, initial symptoms were only irritability and horizontal nystagmus. A computed tomography scan revealed an extra-axial mass lesion that suggested a giant globular extradural hematoma. The patient was submitted to a small exploratory craniectomy to evacuate the blood clot. Surprisingly, the supposed extradural hematoma was, in fact, a chronic subdural hematoma with an unusual shape. After the surgical drainage, the patient remained asymptomatic. No lesion recurrence has been detected so far.

Conclusions The case illustrates a very uncommon and interesting presentation of a common neurosurgical disease. A full characterization of the lesion and its pathophysiology is made, and a particular surgical management is proposed and thoroughly discussed.

Introdução A hidrocefalia é uma condição neurológica frequente na infância. A abordagem mais comum continua sendo o shunt ventricular. Contudo, os problemas de shunt, incluindo a infecção do catéter ou o mal funcionamento do shunt, contribuem para diversas complicações, como hematomas extra-axiais, uma complicação com potencial comprometimento de vida.

Relato de caso Relatamos o caso de uma recém-nascida de 6 meses de idade vítima de trauma cerebral. Ela recebeu previamente um shunt para hidrocefalia obstrutiva consequente de estenose do aqueduto diagnosticada logo após o nascimento. Após o dano cerebral, os sintomas iniciais foram apenas irritabilidade e nistagmo horizontal. received

January 13, 2016

accepted

June 8,2016

published online

August 23, 2016
DOI http://dx.doi.org/

10.1055/s-0036-1585415. ISSN 0103-5355.
Copyright $\odot 2016$ by Thieme-Revinter

Publicações Ltda, Rio de Janeiro, Brazil
License terms

(1) (1) $\Theta \circledast$ 
Tomografia computadorizada revelou uma massa extra-axial lesionada que sugeriu um hematoma globular extradural gigante. A paciente foi submetida a uma pequena craniectomia exploratória para extração do coágulo sanguíneo. Surpreendentemente, o suposto hematoma extradural era, na verdade, um hematoma subdural crônico com formato anormal. Após drenagem cirúrgica, a paciente permaneceu assintomática. Nenhuma lesão recorrente foi detectada até a presente publicação.

Conclusões O caso exemplifica uma apresentação muito incomum e interessante de um distúrbio neurocirúrgico comum. Uma caracterização completa da lesão e de sua patofisiologia é feita, e um procedimento cirúrgico particular é proposto e exaustivamente discutido.

\section{Introduction}

Subdural hematoma is a well-known and well-studied consequence of traumatic brain injury. Furthermore, it may also be observed in spontaneous (non-traumatic) cases, as a complication of ventriculoperitoneal overshunting. ${ }^{1}$ Its mortality and sequela rates may be high if a large and compressive lesion is left surgically untreated. Small acute subdural hematomas (ASH) are frequently managed non-surgically, and in such cases they may become a chronic subdural effusion if they are not reabsorbed.

Surgery is recommended when the patient presents neurological symptoms (regardless of lesion dimensions), or when image studies show mass effect (usually blood clot thickness higher than $1.0-1.5 \mathrm{~cm}$ ). When rebleeding rates are higher than blood reabsorption, there is considerable risk of enlargement of the hematoma, ${ }^{2}$ which may also indicate urgent surgical approach.

Neurosurgical literature has described many efficient techniques for the treatment of chronic subdural hematomas (CSH), such as trepanation, twist-drill craniotomy at bedside, and even large craniotomy/craniectomy. Despite the variety of options for surgical treatment, $\mathrm{CSH}$ has high recurrence rates (3.8-30\%), ${ }^{3}$ and may be a challenge in some particular cases. Nevertheless, most patients have a good outcome, especially the younger ones, and the mortality rate is relatively low within 30 days of the postoperative period (3.2$6.5 \%)$. Most patients (80\%) recover their previous neurological function and have favorable outcomes. ${ }^{4}$ It is important to highlight that the postoperative prognosis and outcome are closely dependent on several factors, including mainly the patient's age and previous neurological status. Aspects of computed tomography (CT) image, such as volume of the lesion and midline shift, are also considered when making the decision to operate or not.

\section{Case}

A 6-month-old infant was admitted to the emergency department presenting with irritability and horizontal nystagmus that started just after she fell from her mother's arms. Interestingly, the child had had another similar fall one month earlier. Moreover, the patient had a shunt device installed in the first weeks after birth because of a hypertensive hydrocephalus caused by aqueductal stenosis.

The CT scan surprisingly revealed a giant biconvex globular-shaped hypodense lesion, resembling a chronified extradural hematoma (-Fig. 1).

We took the patient immediately to the operating room to evacuate the hematoma as soon as possible. Due to its unusual form, we decided to start the operation with a large skin incision, once the main hypothesis was extradural hematoma, and large craniotomies are often advocated as the best treatment for these lesions. Thus, just after making the skin flap, we performed a small exploratory craniectomy just in the coronal fissure and parallel to the anterior fontanel, to inspect the location of the hematoma. Soon after the initial trepanation, no signs of blood clot were found. Therefore, after opening the dura-mater we observed the drain of a hypertensive, dark subdural fluid. Despite the lesion

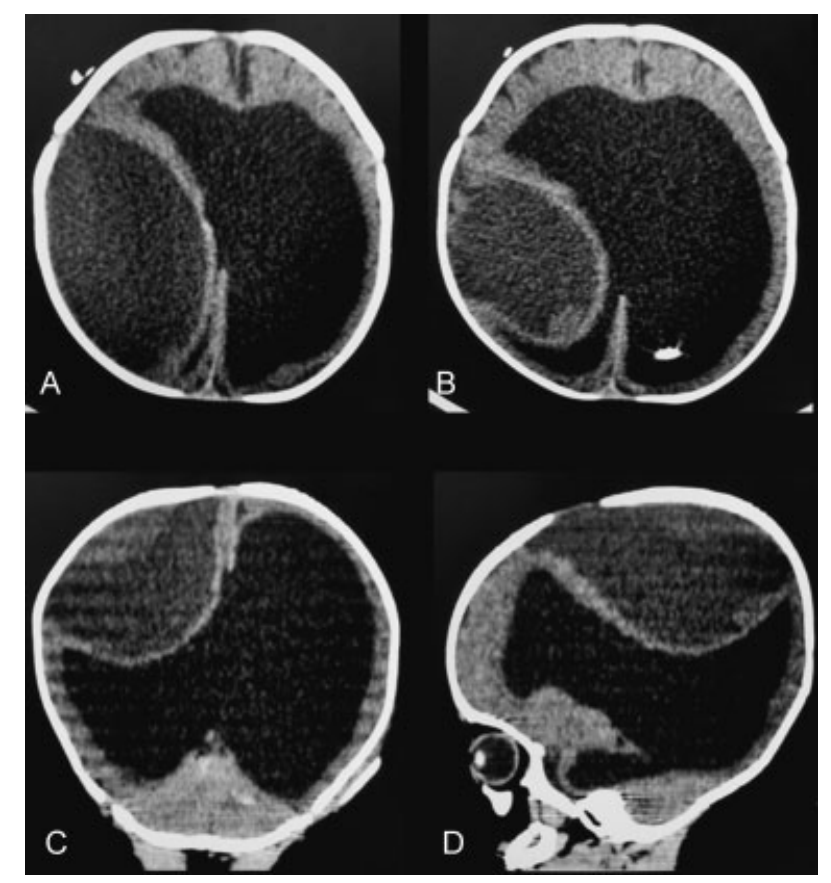

Fig. 1 Preoperative CT: a giant biconvex globular hematoma (A, B) in the axial plane; $(C)$ in the coronal plane; and (D) in the sagittal plane. 
conformation (that resembled, as mentioned, an extradural collection), the effusion was clearly located on the subdural space. The trepanation was enlarged, and the hematoma was drained with no complications during or after the procedure.

A post-operative CT scan showed the placement of the craniectomy and a small subdural residue (-Fig. 2 ).

The patient presented full resolution of the symptoms immediately after surgery. After one year of postoperative follow-up, no signs of new neurological symptoms were observed.

\section{Conclusion}

Ventricular over drainage and consequent extra axial hematomas are common complications of ventriculoperitoneal over shunting. These hematomas most of the times have subdural origin. Epidural bleeding in this context is a rare condition reported in medical literature..$^{5-7}$ Both acute and chronic subdural hematomas may be consequence of ventricular shunting malfunctioning, and surgical treatment may be indicated in some cases depending on the lesion mass effect (thickness of the lesion, cortical compression and midline structure shift), as well as neurological symptoms (for a review, see Requejo et al). ${ }^{8}$

Although a subdural hematoma is a common entity in neurosurgical practice, giant presentations of this lesion are unusual, and only few cases, of variable causes, have been reported in the literature. Mishra et $\mathrm{al}^{1}$ reported a case of a 39-year-old female with congenital hydrocephalus presenting with a giant subdural hematoma on the CT scan. That patient had many episodes of minor head injury, but no ventriculoperitoneal shunt insertion was reported. He and Zhang $^{9}$ also reported a similar case, that of a 15 -year-old adolescent boy with ventriculoperitoneal shunt presenting with a giant subdural hematoma, probably caused by over shunting.

As far as we know, our case is the second case of a globular subdural hematoma reported so far. Murata et $\mathrm{al}^{10}$ have shown a case like ours, in which total hematoma evacuation resolved the symptoms (seizures), and the patient recovered very well. No recurrence was observed during the follow-up time as well. There is also a reported case of giant subdural hematoma with a small globular portion on the medial aspect of the lesion. ${ }^{1}$ After surgical drainage, the patient became asymptomatic, and recovered completely without recurrences in the early postoperative period. Interestingly, all of those cases previously reported were related to large hydrocephalus. Thus, we hypothesized a mechanism for such globular unusual conformation: the extreme large ventricles filled with cerebrospinal fluid and covered by a thin cortical layer may be less resistant to the bleeding/hematoma formation, pushing the cortex and ventricles more centrally than peripherally, thus allowing a globular aspect instead of the classical concave-convex aspect of subdural collections.

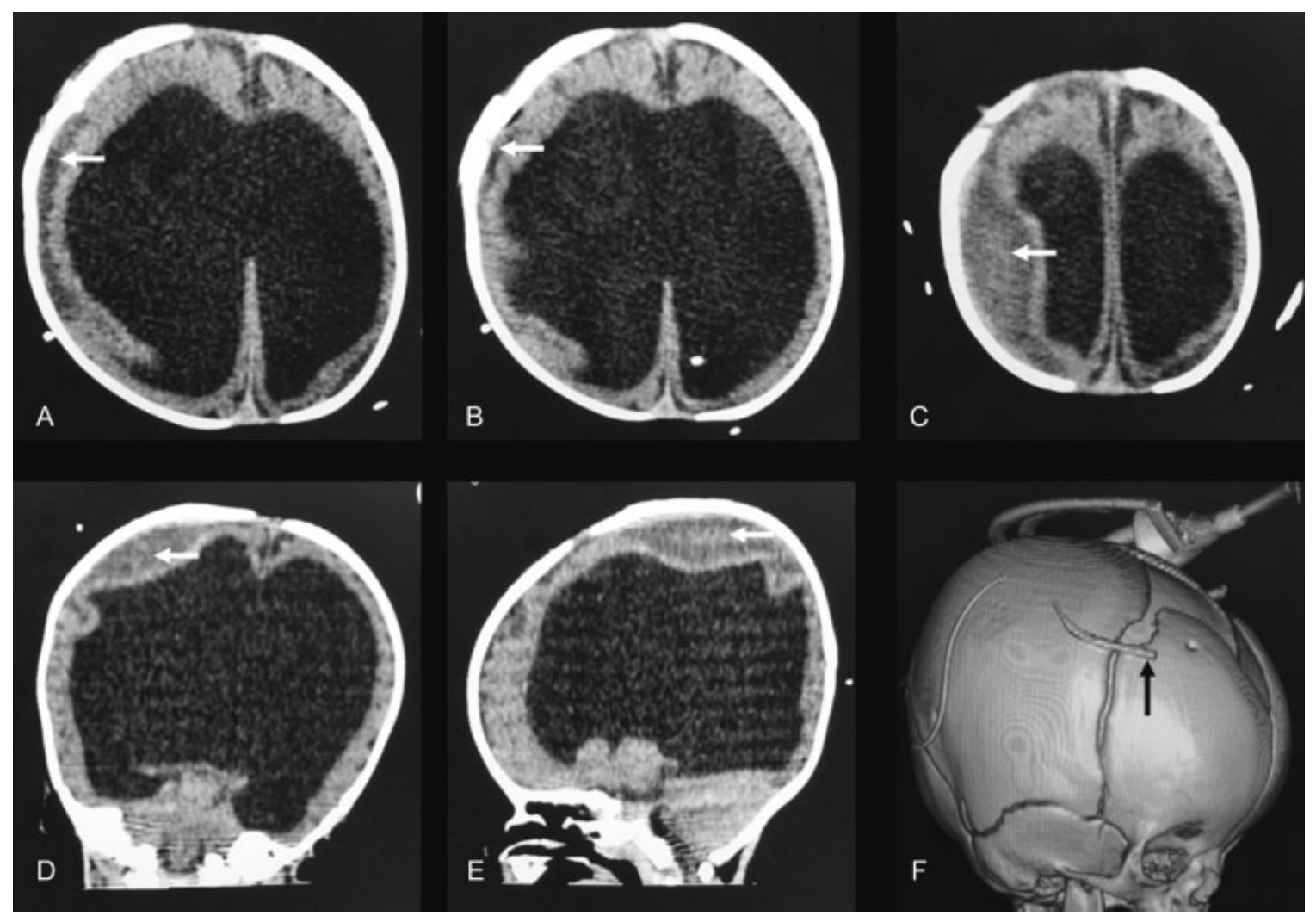

Fig. 2 Postoperative CT scan shows almost complete evacuation of subdural lesion. Only a small residue can be detected (white arrows) (A, B, C) in the axial plane; (D) in the coronal plane; $(E)$ in the sagittal plane; $(F)$ : 3D reconstruction of bone window image showed the placement of the craniectomy and the tip of the extracranial drain (black arrow). 
Our patient presented only nystagmus and irritability as symptoms, and we promptly took her to the operating room. Postoperatively, the patient recovered uneventfully, and remained symptom-free for one year (the follow-up period).

To sum up, giant globular subdural hematomas are very rare lesions, related to extreme hydrocephalus and over shunting. The low relative resistance of the thin parenchymal layer covering the large ventricles and compressed by the overlying hematoma may be a possible cause of this uncommon origin and form. We recommend that globular hematomas must be approached as chronic subdural collections, that is, with small incisions and enlarged trepanations, as advocated by many authors for classic chronic subdural hematomas.

\section{Competing Interests}

The authors declare no competing interests.

\section{Authors' Contributions}

Both authors contributed equally for the work.

\section{Consent}

An informed consent was obtained from the parents of the patient for case publication.

\section{References}

1 Mishra A, Ojha BK, Chandra A, Srivastava C, Singh SK. Giant unusual shaped chronic subdural hematoma in a patient with untreated congenital hydrocephalus. Asian J Neurosurg 2011;6(2):121-122

2 Lee KS. Natural history of chronic subdural haematoma. Brain Inj 2004;18(4):351-358

3 Emich S, Richling B, McCoy MR, et al. The efficacy of dexamethasone on reduction in the reoperation rate of chronic subdural hematoma-the DRESH study: straightforward study protocol for a randomized controlled trial. Trials 2014;15:6

4 Mori K, Maeda M. Surgical treatment of chronic subdural hematoma in 500 consecutive cases: clinical characteristics, surgical outcome, complications, and recurrence rate. Neurol Med Chir (Tokyo) 2001;41(8):371-381

5 Noleto G, Neville IS, Tavares WM, et al. Giant acute epidural hematoma after ventriculoperitoneal shunt: a case report and literature review. Int J Clin Exp Med 2014;7(8):2355-2359

6 Seyıthanoglu H, Guzey FK, Emel E, Ozkan N, Aycan A. Chronic ossified epidural hematoma after ventriculoperitoneal shunt insertion: a case report. Turk Neurosurg 2010;20(4):519-523

7 Louzada PR, Requejo PR, Barroso MV, et al. Bilateral extradural haematoma after acute ventricular over-drainage. Brain Inj 2012; 26(1):95-100

8 Requejo PR, Vaitsman RP, Paiva MS, et al. Interhemispheric chronic subdural haematoma: case report and brief review of the literature. Brain Inj 2010;24(7-8):1039-1043

9 He XS, Zhang X. Giant calcified chronic subdural haematoma: a long term complication of shunted hydrocephalus. J Neurol Neurosurg Psychiatry 2005;76(3):367

10 Murata T, Shigeta H, Horiuchi T, Sakai K, Hongo K. Globular subdural hematoma in a shunt-treated infant: case report. J Neurosurg Pediatr 2010;5(2):210-212 